\title{
Cyclometallated ruthenium(II) carbonyl complexes with 1-pyrenaldehyde 4- $R$-3-thiosemicarbazones: Regioselective ruthenation of the 1-pyrenyl group
}

\author{
RUPESH NARAYANA PRABHU and SAMUDRANIL PAL* \\ School of Chemistry, University of Hyderabad, Hyderabad 500 046, India \\ e-mail: spal@uohyd.ac.in
}

MS received 02 October 2014; revised 21 November 2014; accepted 24 November 2014

\begin{abstract}
A facile method for the synthesis of a series of cyclometallated ruthenium(II) carbonyl complexes with 1-pyrenaldehyde 4- $R$-3-thiosemicarbazones $\left(\mathrm{H}_{2} \mathrm{~L}^{\mathrm{n}}\right.$ where the two $\mathrm{H}$ 's represent the dissociable thioamide and pyrenyl protons; $R=\mathrm{H}, \mathrm{Me}$ and $\mathrm{Ph}$ ) has been described. The characterization of the complexes having the general molecular formula trans $-\left[\mathrm{Ru}\left(\mathrm{L}^{\mathrm{n}}\right)(\mathrm{CO})\left(\mathrm{EPh}_{3}\right)_{2}\right]($ where $\mathrm{E}=\mathrm{P}$ or As) were accomplished by elemental $(\mathrm{CHN})$ analysis, magnetic susceptibility and spectroscopic (ESI-MS, IR, UV-Vis, emission and ${ }^{1} \mathrm{H}-\mathrm{NMR}$ ) measurements. Electronic spectra of the complexes display multiple strong absorptions in the range 440-224 nm due to intraligand transitions. All the complexes exhibit emission bands that are characteristic of ligand centred emissive states. X-ray diffraction studies with representative complexes reveal a pincer-like 5,5-membered fused chelate rings forming CNS coordination mode of the thiosemicarbazonate ligand $\left(\mathrm{L}^{\mathrm{n}}\right)^{2-}$ via regioselective activation of 1-pyrenyl ortho $\mathrm{C}-\mathrm{H}$ and formation of a distorted octahedral $\mathrm{C}_{2} \mathrm{NSE}_{2}$ coordination sphere around the ruthenium(II) centre.
\end{abstract}

Keywords. Ruthenium(II) carbonyl; thiosemicarbazones; ortho-ruthenation; regioselective; crystal structure; physical properties.

\section{Introduction}

The intramolecular activation of aromatic $\mathrm{C}-\mathrm{H}$ bonds of coordinated ligands by transition metals and the resulting cyclometallates represent an active area of research in the context of regiospecific organic and organometallic synthesis, catalysis, photochemistry, materials science, biological and pharmaceutical chemistry, etc. ${ }^{1-8}$ Such a wide range of applications has prompted a continuous quest for new cyclometallated complexes with diverse types of ligands. Among cyclometallated complexes, the pincer-type species bearing mono- or di- or trianionic terdentate backbone have emerged as a unique class of organometallic compounds mostly owing to their applications not only as efficient homogeneous catalysts in various chemical transformations $^{9-11}$ but also as sensors and molecular switches. ${ }^{12-14}$ The rigid nature and the strong coordination ability of the pincer ligands make their complexes robust and less sensitive to air and moisture. ${ }^{15,16}$

We have reported some cyclometallated platinum group metal ion complexes with pincer-like CNOdonor Schiff bases derived from aroylhydrazines and various mono- and polycyclic aromatic aldehydes. ${ }^{17-26}$

\footnotetext{
*For correspondence
}

The Schiff bases obtained from monocyclic aromatic aldehydes can provide only ortho-metallated complexes having 5,5-membered fused chelate rings. ${ }^{17-20}$ On the other hand, depending upon the position of the azomethine fragment, Schiff bases derived from polycyclic aromatic aldehydes can provide either of the ortho or the peri positions of the polycyclic aryl group (3-indolyl, 1-naphthalenyl or 1-pyrenyl) as the metallation site and form 5,5- or 6,5-membered fused chelate rings. ${ }^{21-26}$ Generally peri-metallates of rhodium(III) $)^{26}$ and palladium(II) ${ }^{21-23,26}$ and orthometallates of ruthenium(III), ${ }^{24,25}$ iridium(III) and platinum(II) ${ }^{26}$ have been isolated with this type of ligands. Recently we have tried to synthesize cycloruthenates with potentially CNS-donor thiobenzhydrazones of some polycyclic aromatic aldehydes and explore if any regioselective ortho-ruthenation of the polycyclic aryl group occurs or not. However, in the isolated ruthenium(II) complexes, the thiobenzhydrazonates act as four-membered chelate ring forming thioamidate$\mathrm{N}, \mathrm{S}$ donor $^{27}$ instead of the CNS-donor. Interestingly, analogous monocyclic aromatic aldehyde thiosemicarbazones are known to provide ortho-ruthenated complexes having 5,5-membered fused chelate rings, where the ligands act as CNS-donor. ${ }^{28-32}$ It may be noted that among various Schiff bases containing nitrogen and 

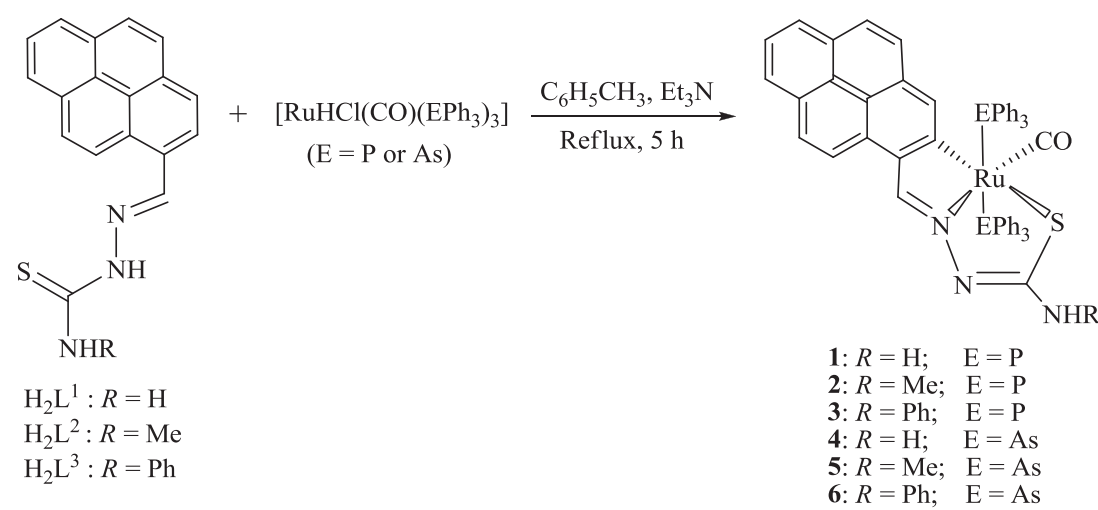

Scheme 1. Synthesis of the cyclometallated ruthenium(II) complexes.

sulphur donor atoms, thiosemicarbazones are quite unique with respect to their selectivity, sensitivity and the ability to adopt a variety of coordination modes towards various metal ions..$^{32,33}$ In view of the above facts, we have invesigated the ruthenium(II) coordination chemistry with 1-pyrenaldehyde 4- $R-3$ thiosemicarbazones $\left(\mathrm{H}_{2} \mathrm{~L}^{\mathrm{n}}\right.$, where the two H's represent the dissociable thioamide and pyrenyl protons) (scheme 1). The 1-pyrenyl moiety in $\mathrm{H}_{2} \mathrm{~L}^{\mathrm{n}}$ provides both ortho and peri positions as potential metallation sites. Thus, our objective was to explore whether the 1-pyrenyl moiety of the ligand gets metallated in a regioselctive way or not. In this effort, we have isolated a series of exclusively ortho-metallated ruthenium(II) carbonyl complexes. Herein, we describe the syntheses, characterization and physical properties of these complexes with the X-ray structures of two representative complexes.

\section{Experimental}

\subsection{Materials}

$\left[\mathrm{RuHCl}(\mathrm{CO})\left(\mathrm{PPh}_{3}\right)_{3}\right]$ and $\left[\mathrm{RuHCl}(\mathrm{CO})\left(\mathrm{AsPh}_{3}\right)_{3}\right]$ were prepared by following literature methods. ${ }^{34,35}$ All other chemicals used in this work were of analytical grade available commercially and were used as supplied. The solvents used were purified by following standard methods. ${ }^{36}$

\subsection{Physical measurements}

Microanalyses (CHN) were performed by using a Thermo Finnigan Flash EA1112 series elemental analyzer. Magnetic susceptibility measurements were performed with the help of a Sherwood scientific balance. A Digisun DI-909 conductivity meter was used to measure the solution electrical conductivities. A Shimadzu LCMS 2010 liquid chromatograph mass spectrometer was used to verify the purity of the Schiff bases $\left(\mathrm{H}_{2} \mathrm{~L}^{1-3}\right)$. A Bruker Maxis HRMS (ESI-TOF analyzer) spectrometer was used to record the mass spectra. The infrared spectra were recorded on a Jasco5300 FT-IR spectrophotometer by using $\mathrm{KBr}$ pellets in the region $400-4000 \mathrm{~cm}^{-1}$. The ${ }^{1} \mathrm{H}$ NMR spectra were recorded with the help of Bruker $400 \mathrm{MHz}$ spectrometer. A Shimadzu UV-3600 UV-Vis-NIR spectrophotometer was used to collect the electronic spectra. The emission spectroscopic measurements were performed on a Horiba Jobin Yvon Fluoromax-4 spectrofluorometer. The emission quantum yields were determined relative to that of quinine sulfate $(\Phi=0.546$ in $1 \mathrm{~N}$ $\left.\mathrm{H}_{2} \mathrm{SO}_{4}\right) .{ }^{37}$

\subsection{Synthesis of trans-[Ru(L $\left.\left.L^{1}\right)(C O)\left(P P h_{3}\right)_{2}\right]$ (1)}

$\left[\mathrm{RuHCl}(\mathrm{CO})\left(\mathrm{PPh}_{3}\right)_{3}\right](95 \mathrm{mg}, 0.1 \mathrm{mmol})$ and triethylamine $(0.5 \mathrm{~mL})$ were added to a suspension of $\mathrm{H}_{2} \mathrm{~L}^{1}$ (30 mg, $0.1 \mathrm{mmol})$ in toluene $(20 \mathrm{~mL})$. The reaction mixture was refluxed for $5 \mathrm{~h}$ under an atmosphere of nitrogen and the progress of the reaction was monitored using TLC. At the end of the reaction, the solution was concentrated to $c a .3 \mathrm{~mL}$ and $n$-hexane was added whereby solid separated out. This material was collected by filtration and transferred to a silica gel column packed with $n$-hexane. The first moving yellow band containing the unreacted $\mathrm{H}_{2} \mathrm{~L}^{1}$ was eluted with ethyl acetate/ $n$-hexane (1:9) and discarded. The following red band containing the complex 1 was eluted using methanol/chloroform (1:4). The red solution thus obtained was evaporated to dryness and the complex was collected as dark red solid. Yield was $65 \mathrm{mg}(68 \%)$. Anal. calcd. for $\mathrm{C}_{55} \mathrm{H}_{41} \mathrm{~N}_{3} \mathrm{OP}_{2} \mathrm{RuS}$ : C, 69.17; H, 4.33; N, 4.40. Found: C, 69.32; H, 4.29; N, 4.48. ESI-MS Found (calcd.) $\mathrm{m} / \mathrm{z}\{\mathrm{M}+\mathrm{H}\}^{+}: 956.157$ (956.1568). Selected IR bands $\left(\mathrm{cm}^{-1}\right): 1923 v_{\mathrm{C} \equiv \mathrm{O}}, 1578$ $v_{\mathrm{C}=\mathrm{N}}$. Selected ${ }^{1} \mathrm{H}$ NMR data $(\delta \mathrm{ppm}): 10.2(\mathrm{~s}, 1 \mathrm{H}$, $\mathrm{CH}=\mathrm{N}), 8.2\left(\mathrm{~s}, 2 \mathrm{H}, \mathrm{NH}_{2}\right)$. UV-Vis bands $\left(\lambda_{\max }(\mathrm{nm})(\varepsilon\right.$ 
$\left.\left.\left(10^{4} \mathrm{M}^{-1} \mathrm{~cm}^{-1}\right)\right)\right): 428(4.2), 408$ (4.6), $372 \mathrm{sh}(3.3), 284$ (3.8), $226(9.5)$. Emission bands $\left(\lambda_{\max }(\mathrm{nm})\left(\lambda_{\text {exc }}(\mathrm{nm})\right)\right)$ : 470, 432, 406, 388 (310).

\subsection{Synthesis of trans-[Ru( $\left.\left.L^{2}\right)(C O)\left(P P h_{3}\right)_{2}\right](2)$}

This complex was synthesized in $65 \%$ yield by following the same procedure as described above for 1 using $\mathrm{H}_{2} \mathrm{~L}^{2}$ instead of $\mathrm{H}_{2} \mathrm{~L}^{1}$. Anal. calcd. for $\mathrm{C}_{56} \mathrm{H}_{43} \mathrm{~N}_{3} \mathrm{OP}_{2} \mathrm{RuS}$ : C, 69.41; H, 4.47; N, 4.34. Found: C, 69.58; H, 4.53; N, 4.26. ESI-MS Found (calcd.) $\mathrm{m} / \mathrm{z}\{\mathrm{M}+\mathrm{H}\}^{+}: 970.201$ (970.1725). Selected IR bands $\left(\mathrm{cm}^{-1}\right): 1918 v_{\mathrm{C} \equiv \mathrm{O}}, 1584 v_{\mathrm{C}=\mathrm{N}}$. Selected ${ }^{1} \mathrm{H}$ NMR data $(\delta \mathrm{ppm}): 10.2(\mathrm{~s}, 1 \mathrm{H}, \mathrm{CH}=\mathrm{N}), 8.1(\mathrm{~s}, 1 \mathrm{H}, \mathrm{NHR}), 3.2$ $\left(\mathrm{d}, 3 \mathrm{H}, \mathrm{NCH}_{3}\right)$. UV-Vis bands $\left(\lambda_{\max }(\mathrm{nm})\left(\varepsilon\left(10^{4} \mathrm{M}^{-1}\right.\right.\right.$ $\left.\left.\mathrm{cm}^{-1}\right)\right)$ ): 435 (4.2), 412 (4.4), 391sh (3.1), 284 (3.3), 226 (8.5). Emission bands $\left(\lambda_{\max }(\mathrm{nm})\left(\lambda_{\text {exc }}(\mathrm{nm})\right)\right)$ : 480 , 434, 408, 388 (310).

\subsection{Synthesis of trans-[Ru( $\left.\left.\mathrm{L}^{3}\right)(\mathrm{CO})\left(\mathrm{PPh}_{3}\right)_{2}\right](3)$}

The procedure used for the synthesis of $\mathbf{3}$ was identical with that described for $\mathbf{1}$ except for the use of $\mathrm{H}_{2} \mathrm{~L}^{3}$ instead of $\mathrm{H}_{2} \mathrm{~L}^{1}$. Yield was $72 \%$. Anal. calcd. for $\mathrm{C}_{61} \mathrm{H}_{45} \mathrm{~N}_{3} \mathrm{OP}_{2} \mathrm{RuS}$ : C, 63.34; H, 3.96; N, 4.03. Found: C, 63.45; H, 3.89; N, 4.12. ESI-MS Found (calcd.) m/z $\{\mathrm{M}+\mathrm{H}\}^{+}: 1032.205$ (1032.1881). Selected IR bands $\left(\mathrm{cm}^{-1}\right): 1956 v_{\mathrm{C} \equiv O}, 1578 v_{\mathrm{C}=\mathrm{N}}$. Selected ${ }^{1} \mathrm{H}$ NMR data $(\delta \mathrm{ppm}): 10.6(\mathrm{~s}, 1 \mathrm{H}, \mathrm{CH}=\mathrm{N}), 8.2(\mathrm{~s}, 1 \mathrm{H}, \mathrm{NHR})$. UVVis bands $\left(\lambda_{\max }(\mathrm{nm})\left(\varepsilon\left(10^{4} \mathrm{M}^{-1} \mathrm{~cm}^{-1}\right)\right)\right): 425$ (4.3), 405 (4.7), 370sh (3.4), 284 (3.9), 224 (9.7). Emission bands $\left(\lambda_{\max }(\mathrm{nm})\left(\lambda_{\text {exc }}(\mathrm{nm})\right)\right)$ : 472, 430, 408, $386(310)$.

\subsection{Synthesis of trans- $\left[R u\left(L^{1}\right)(C O)\left(A s P h_{3}\right)_{2}\right](4)$}

This complex was synthesized in $70 \%$ yield by following the same procedure as described for $\mathbf{1}$ except that $\left[\mathrm{RuHCl}(\mathrm{CO})\left(\mathrm{AsPh}_{3}\right)_{3}\right]$ was used instead of $\left[\mathrm{RuHCl}(\mathrm{CO})\left(\mathrm{PPh}_{3}\right)_{3}\right]$ as the ruthenium(II) precursor. Anal. calcd. for $\mathrm{C}_{55} \mathrm{H}_{41} \mathrm{As}_{2} \mathrm{~N}_{3} \mathrm{ORuS}$ : C, 71.05; H, 4.40; $\mathrm{N}, 4.08$. Found: C, 71.26; H, 4.31; N, 3.96. ESI-MS Found (calcd.) $\mathrm{m} / \mathrm{z}\{\mathrm{M}+\mathrm{H}\}^{+}: 1044.052$ (1044.0525). Selected IR bands $\left(\mathrm{cm}^{-1}\right): 1923 v_{\mathrm{C} \equiv \mathrm{O}}, 1585 v_{\mathrm{C}=\mathrm{N}}$. Selected ${ }^{1} \mathrm{H}$ NMR data $(\delta \mathrm{ppm}): 10.0(\mathrm{~s}, 1 \mathrm{H}, \mathrm{CH}=\mathrm{N})$, $8.3\left(\mathrm{~s}, 2 \mathrm{H}, \mathrm{NH}_{2}\right)$. UV-Vis bands $\left(\lambda_{\max }(\mathrm{nm})\left(\varepsilon\left(10^{4} \mathrm{M}^{-1}\right.\right.\right.$ $\left.\left.\left.\mathrm{cm}^{-1}\right)\right)\right)$ : 431 (3.0), 408 (3.4), 375sh (2.5), 286 (2.8), 226 (7.2). Emission bands $\left(\lambda_{\max }(\mathrm{nm})\left(\lambda_{\mathrm{exc}}(\mathrm{nm})\right)\right)$ : 480 , 434, 408, 388 (310).

\subsection{Synthesis of trans- $\left[R u\left(L^{2}\right)(C O)\left(A s P h_{3}\right)_{2}\right](5)$}

The procedure used for the synthesis of 5 using $\mathrm{H}_{2} \mathrm{~L}^{2}$ instead of $\mathrm{H}_{2} \mathrm{~L}^{1}$ was very similar to that employed for
4. Yield was $67 \%$. Anal. calcd. for $\mathrm{C}_{56} \mathrm{H}_{43} \mathrm{As}_{2} \mathrm{~N}_{3} \mathrm{ORuS \text {: }}$ C, 63.64; H, 4.10; N, 3.98. Found: C, 63.54; H, 4.21; N, 3.86. ESI-MS Found (calcd.) $\mathrm{m} / \mathrm{z}\{\mathrm{M}+\mathrm{H}\}^{+}: 1058.068$ (1058.0681). Selected IR bands $\left(\mathrm{cm}^{-1}\right): 1923 v_{\mathrm{C} \equiv 0}$, $1555 v_{\mathrm{C}=\mathrm{N}}$. Selected ${ }^{1} \mathrm{H}$ NMR data $(\delta \mathrm{ppm}): 10.3$ (s, $1 \mathrm{H}$, $\mathrm{CH}=\mathrm{N}), 8.2(\mathrm{~s}, 1 \mathrm{H}, \mathrm{NHR}), 3.1\left(\mathrm{~d}, 3 \mathrm{H}, \mathrm{NCH}_{3}\right)$. UV-Vis bands $\left(\lambda_{\max }(\mathrm{nm})\left(\varepsilon\left(10^{4} \mathrm{M}^{-1} \mathrm{~cm}^{-1}\right)\right)\right): 435(3.8), 412$ (4.0), 390sh (2.9), 284 (3.1), 227 (7.7). Emission bands $\left(\lambda_{\max }(\mathrm{nm})\left(\lambda_{\text {exc }}(\mathrm{nm})\right)\right): 476,430,406,386(310)$.

\subsection{Synthesis of trans- $\left[R u\left(L^{3}\right)(C O)\left(A s P h_{3}\right)_{2}\right](6)$}

Like 5, $\mathbf{6}$ was also synthesized in $70 \%$ yield by following the same procedure as employed for 4 using $\mathrm{H}_{2} \mathrm{~L}^{3}$ instead of $\mathrm{H}_{2} \mathrm{~L}^{1}$. Anal. calcd. for $\mathrm{C}_{61} \mathrm{H}_{45} \mathrm{As}_{2} \mathrm{~N}_{3} \mathrm{ORuS}$ : C, 65.47; H, 4.05; N, 3.76. Found: C, 64.58; H, 4.12; N, 3.65. ESI-MS Found (calcd.) $\mathrm{m} / \mathrm{z}\{\mathrm{M}+\mathrm{H}\}^{+}: 1120.084$ (1120.0838). Selected IR bands $\left(\mathrm{cm}^{-1}\right): 1940 v_{\mathrm{C} \equiv \mathrm{O}}$, $1555 v_{\mathrm{C}=\mathrm{N}} .{ }^{1} \mathrm{H}$ NMR $\left(400 \mathrm{MHz}, \mathrm{CDCl}_{3}\right)(\delta \mathrm{ppm})$ : $10.6(\mathrm{~s}, 1 \mathrm{H}, \mathrm{CH}=\mathrm{N}), 8.1$ (s, 1H, NHR). UV-Vis bands $\left(\lambda_{\max }(\mathrm{nm})\left(\varepsilon\left(10^{4} \mathrm{M}^{-1} \mathrm{~cm}^{-1}\right)\right)\right): 439$ (3.1), 421 (3.4), 377sh (2.3), 277 (3.9), 228 (8.0). Emission bands $\left(\lambda_{\max }(\mathrm{nm})\left(\lambda_{\text {exc }}(\mathrm{nm})\right)\right): 474,428,406,386(310)$.

\section{$2.9 \quad$ X-ray crystallography}

Single crystals of trans-[Ru( $\left.\left(\mathrm{L}^{1}\right)(\mathrm{CO})\left(\mathrm{PPh}_{3}\right)_{2}\right] \quad$ (1) and trans-[Ru( $\left.\left.\mathrm{L}^{3}\right)(\mathrm{CO})\left(\mathrm{PPh}_{3}\right)_{2}\right]$ (3) were obtained by slow evaporation of their chloroform-acetonitrile (1:1) solutions at room temperature. 1 crystallizes as 1. $\mathrm{CHCl}_{3} \cdot 0.5 \mathrm{CH}_{3} \mathrm{CN}$, while $\mathbf{3}$ crystallizes as it is without any solvent molecule. Determination of the unit cell parameters and the intensity data collections at $298 \mathrm{~K}$ were carried out using monochromated Mo $K_{\alpha}$ radiation $(\lambda=0.71073 \AA)$ on Bruker-Nonius SMART APEX CCD and Oxford Diffraction Xcalibur Gemini single crystal X-ray diffractometers for 1. $\mathrm{CHCl}_{3} \cdot 0.5 \mathrm{CH}_{3} \mathrm{CN}$ and 3 , respectively. In the case of $1 \cdot \mathrm{CHCl}_{3} \cdot 0.5 \mathrm{CH}_{3} \mathrm{CN}$, the SMART and the SAINTPlus packages ${ }^{38}$ were used for data acquisition and data extraction, respectively and SADABS program ${ }^{39}$ was used for absorption correction. The CrysAlisPro software $^{40}$ was used for data collection, reduction and absorption correction for $\mathbf{3}$. The structures were solved by direct methods and refined by full-matrix least squares procedures using SIR92 ${ }^{41}$ and SHELXL-97 ${ }^{42}$ programs, respectively. Both programs were accessed through the WinGX package. ${ }^{43}$ In $1 \cdot \mathrm{CHCl}_{3} \cdot 0.5 \mathrm{CH}_{3} \mathrm{CN}$, the half occupancy acetonitrile molecule is disordered across an inversion centre and it was refined isotropically with geometric restraints. Four carbon atoms of the phenyl ring of $\left(\mathrm{L}^{3}\right)^{2-}$ in $\mathbf{3}$ are also disordered over eight half occupancy sites. These disordered 
Table 1. Selected crystal data and structure refinement summary.

\begin{tabular}{|c|c|c|}
\hline Complex & $\mathbf{1} \cdot \mathrm{CHCl}_{3} \cdot 0.5 \mathrm{CH}_{3} \mathrm{CN}$ & 3 \\
\hline Chemical formula & $\mathrm{C}_{57} \mathrm{H}_{43.5} \mathrm{Cl}_{3} \mathrm{~N}_{3.5} \mathrm{OP}_{2} \mathrm{RuS}$ & $\mathrm{C}_{61} \mathrm{H}_{45} \mathrm{~N}_{3} \mathrm{OP}_{2} \mathrm{RuS}$ \\
\hline Formula weight & 1094.87 & 1031.07 \\
\hline Crystal system & Triclinic & Orthorhombic \\
\hline Space group & $P_{\overline{1}}^{-}$ & $P$ bca \\
\hline$a(\AA)$ & $12.576(4)$ & $12.6567(12)$ \\
\hline$b(\AA)$ & $14.883(4)$ & $25.2693(16)$ \\
\hline$c(\AA)$ & $15.289(5)$ & $31.295(3)$ \\
\hline$\alpha\left(^{\circ}\right)$ & $74.522(5)$ & 90 \\
\hline$\beta\left(^{\circ}\right)$ & $75.335(5)$ & 90 \\
\hline$\gamma\left({ }^{\circ}\right)$ & $68.668(5)$ & 90 \\
\hline Volume $\left(\AA^{3}\right)$ & $2529.9(13)$ & $10008.9(14)$ \\
\hline $\mathrm{Z}$ & 2 & 8 \\
\hline$\rho\left(\mathrm{g} \mathrm{cm}^{-3}\right)$ & 1.437 & 1.368 \\
\hline$\mu\left(\mathrm{mm}^{-1}\right)$ & 0.617 & 0.465 \\
\hline Reflections collected & 17599 & 24789 \\
\hline Reflections unique & 8815 & 8793 \\
\hline Reflections $[I \geq 2 \sigma(I)]$ & 5110 & 2949 \\
\hline Data / restraints / parameters & 8815 / 3 / 616 & 8793 / 29 / 619 \\
\hline$R 1, w R 2[I \geq 2 \sigma(I)]$ & $0.0801,0.1699$ & $0.0827,0.1164$ \\
\hline Goodness-of-fit on $F^{2}$ & 0.977 & 0.882 \\
\hline Max. / Min. peaks $\left(\mathrm{e} \AA^{-3}\right)$ & $1.065,-0.743$ & $0.822 /-0.397$ \\
\hline
\end{tabular}

carbon atoms were refined isotropically with geometric restraints. The remaining non-hydrogen atoms with full site occupancies in both $1 \cdot \mathrm{CHCl}_{3} \cdot 0.5 \mathrm{CH}_{3} \mathrm{CN}$ and 3 were refined anisotropically. The hydrogen atoms in both structures were included in the structure factor calculations at idealized positions by using a riding model. The Platon ${ }^{44}$ and the Mercury ${ }^{45}$ packages were used for molecular graphics. Selected crystal data and structure refinement summary for the two structures are listed in table 1.

\section{Results and Discussion}

\subsection{Synthesis and some properties}

The 1-pyrenaldehyde 4- $R$-3-thiosemicarbazones $(R=$ $\mathrm{H}, \mathrm{Me}$ and $\mathrm{Ph})\left(\mathrm{H}_{2} \mathrm{~L}^{\mathrm{n}}\right)$ were prepared in $\sim 80 \%$ yields by condensation reactions of equimolar amounts of 1-pyrenecarboxaldehyde with the corresponding substituted thiosemicarbazides in acidic ethanol by following a procedure reported earlier. ${ }^{46}$ The purity and identities of all the thiosemicarbazones $\left(\mathrm{H}_{2} \mathrm{~L}^{\mathrm{n}}\right)$ were authenticated by microanalytical (CHN) and spectroscopic (IR, ${ }^{1} \mathrm{H}-\mathrm{NMR}$, LC-MS and UV-Vis) measurements. Reactions of $\left[\mathrm{RuHCl}(\mathrm{CO})\left(\mathrm{EPh}_{3}\right)_{3}\right]$ (where $\mathrm{E}=$ $\mathrm{P}$ or As) with $\mathrm{H}_{2} \mathrm{~L}^{\mathrm{n}}$ in presence of excess triethylamine in toluene under reflux afforded cyclometallated ruthenium(II) carbonyl complexes of the general molecular formula trans- $\left[\mathrm{Ru}\left(\mathrm{L}^{\mathrm{n}}\right)(\mathrm{CO})\left(\mathrm{EPh}_{3}\right)_{2}\right](\mathbf{1}(\mathrm{n}=1, \mathrm{E}=\mathrm{P})$, $2(\mathrm{n}=2, \mathrm{E}=\mathrm{P}), \mathbf{3}(\mathrm{n}=3, \mathrm{E}=\mathrm{P}), \mathbf{4}(\mathrm{n}=1, \mathrm{E}=$ As), $5(\mathrm{n}=2, \mathrm{E}=\mathrm{As}), \mathbf{6}(\mathrm{n}=3, \mathrm{E}=\mathrm{As}))$ in reasonably good $(65-72 \%)$ yields (scheme 1$)$. The elemental analysis and ESI-MS spectroscopic data of 1-6 are consistent with the corresponding proposed molecular formulas of the neutral mononuclear complexes. The diamagnetic nature of $\mathbf{1}-\mathbf{6}$ confirms the +2 oxidation state and the low-spin character of the metal centre in each complex. All the complexes are found to be non-hygroscopic and air stable in solution and in the solid state at room temperature. They are soluble in common organic solvents such as toluene, chloroform, dichloromethane, acetonitrile, methanol, dimethylformamide and dimethyl sulphoxide producing intense red solutions. None of the six complexes is electrically conductive in solution.

\subsection{Spectroscopic characteristics}

The selected infrared absorption bands for all the complexes are given in the experimental section. The characteristic bands associated with the thioamide $\mathrm{N}-\mathrm{H}$ and $\mathrm{C}=\mathrm{S}$ groups (at $\sim 3150$ and $\sim 833 \mathrm{~cm}^{-1}$, respectively) observed for free $\mathrm{H}_{2} \mathrm{~L}^{\mathrm{n}}$ are absent in the spectra of their complexes (1-6). Absence of these bands indicates coordination of the thioamidate-S to the ruthenium(II) centre in the complexes. ${ }^{28,47-50}$ The complexes display the $v_{\mathrm{C}=\mathrm{N}}$ stretch in the region $1555-1585 \mathrm{~cm}^{-1}$ which is at a lower frequency than that of the free $\mathrm{H}_{2} \mathrm{~L}^{\mathrm{n}}(\sim 1600$ 
$\mathrm{cm}^{-1}$ ) indicating coordination of the azomethine nitrogen to the metal centre. ${ }^{28,48-50}$ The typical strong band for the terminally coordinated carbonyl group in $\mathbf{1 - 6}$ is observed in the range 1918-1956 $\mathrm{cm}^{-1} \cdot{ }^{29,32,48,50}$ Three strong bands displayed by all the complexes at $\sim 520$, $\sim 695$ and $\sim 745 \mathrm{~cm}^{-1}$ are attributed to the metal coordinated $\mathrm{EPh}_{3}$ ligands. ${ }^{19,20,24,25,29,32}$

The ${ }^{1} \mathrm{H}-\mathrm{NMR}$ spectra of $\mathbf{1 - 6}$ were recorded in $\mathrm{CDCl}_{3}$ and compared to the spectra of $\mathrm{H}_{2} \mathrm{~L}^{\mathrm{n}}$ recorded in $\left(\mathrm{CD}_{3}\right)_{2} \mathrm{SO}$. A singlet observed at $\delta \sim 11.7 \mathrm{ppm}$ for the free $\mathrm{H}_{2} \mathrm{~L}^{\mathrm{n}}$ is assigned to the thioamide $-\mathrm{NH}-\mathrm{C}(=\mathrm{S})-$ proton. ${ }^{47,49}$ Absence of this signal in the spectra of the complexes supports the deprotonation and the thioamidate-S coordination to the metal centre. The singlet corresponding to the azomethine proton in $\mathrm{H}_{2} \mathrm{~L}^{\mathrm{n}}$ is observed within $\delta 9.4-9.2 \mathrm{ppm}$, while it is observed in the range $\delta 10.6-10.0 \mathrm{ppm}$ for the complexes. The downfield shift suggests deshielding of the azomethine proton due to its coordination to the metal centre. ${ }^{50,51}$ The methyl protons in each of $\mathrm{H}_{2} \mathrm{~L}^{2}, \mathbf{2}$ and $\mathbf{5}$ resonate as a doublet at $\delta \sim 3.10 \mathrm{ppm}(J=5-7 \mathrm{~Hz})$. The remaining protons of $\left(\mathrm{L}^{\mathrm{n}}\right)^{2-}$ and $\mathrm{PPh}_{3} / \mathrm{AsPh}_{3}$ ligands in 1-6 appear as multiplets in the region $\delta 6.9-8.5 \mathrm{ppm}$.

The electronic spectral profiles of $\mathbf{1}-\mathbf{6}$ recorded in acetonitrile are comparable except for some small shifts in the band positions (figure 1). They display five intense absorptions in the wavelength range 440-224 $\mathrm{nm}$. The spectrum reported for $\mathrm{H}_{2} \mathrm{~L}^{1}$ in acetonitrile $\mathrm{e}^{46}$ is very similar to that of $\mathbf{1}$ except for the red shift (by $\sim 25 \mathrm{~nm}$ ) of the three lowest energy absorptions in the complex. The same trend was observed for the remaining five complexes when their spectral profiles were compared with the corresponding free thiosemicarbazones. Thus the absorptions in the visible region

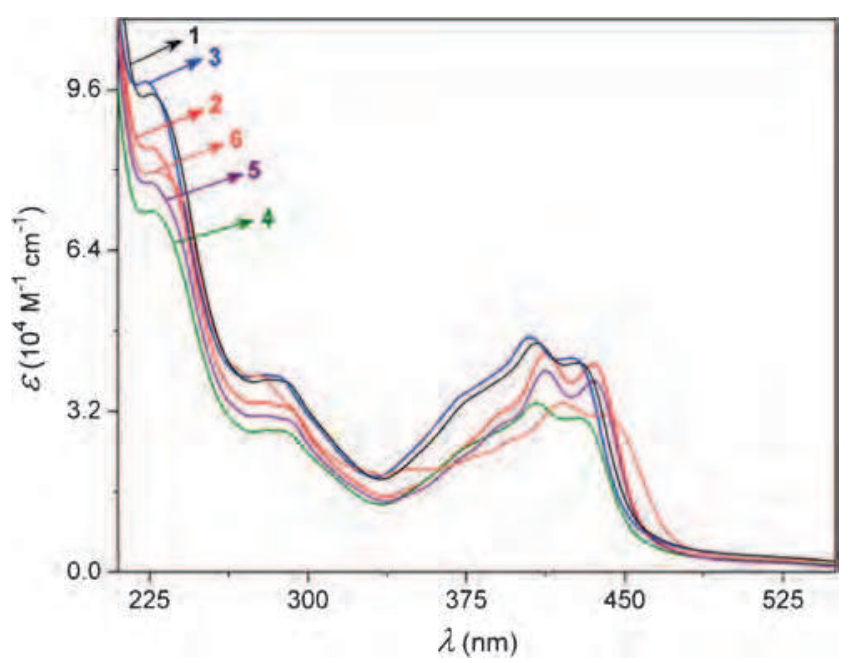

Figure 1. Electronic spectra of trans-[Ru( $\left.\left.\mathrm{L}^{\mathrm{n}}\right)(\mathrm{CO})\left(\mathrm{EPh}_{3}\right)_{2}\right]$ $(\mathbf{1 - 6})$ in acetonitrile. are assigned to the ligand centred transitions rather than charge transfer transitions. Further, upon varying the solvent from toluene to dimethylformamide, it was observed that these lowest energy bands of the complexes are practically insensitive to the solvent polarity. This insensitivity indicates that these are most probably due to the $\pi-\pi *$ transitions associated with the polycyclic aromatic fragment of the ligand. ${ }^{52}$ The red shift of these absorptions in the complexes is generally attributed to the perturbation in the energy levels due to coordination of the metal centre to the aromatic ring of the ligand..$^{23,26,27,52}$

The room temperature emission spectroscopic properties of the thiosemicarbazones $\left(\mathrm{H}_{2} \mathrm{~L}^{1-3}\right)$ and the complexes $(\mathbf{1}-\mathbf{6})$ at a concentration of $\sim 10^{-5} \mathrm{M}$ in degassed dimethylformamide and acetonitrile, respectively were investigated using excitation wavelength as $310 \mathrm{~nm}$. The emission spectra of $\mathrm{H}_{2} \mathrm{~L}^{1-3}$ are very similar. Each spectrum shows a broad emission band centred at $\sim 450 \mathrm{~nm}$ with a shoulder on either side (figure S1, supplementary information). The emission spectral profiles of 1-6 are also quite similar to each other. They display four bands in the wavelength range of 480-386 nm (figure 2). As noted in the electronic spectra (vide supra), the lowest energy, rather broad emission band exhibited by the complexes is also red shifted by $\sim 25 \mathrm{~nm}$ in comparison to the broad emission band observed for the free thiosemicarbazones $\left(\mathrm{H}_{2} \mathrm{~L}^{\mathrm{n}}\right)$. The emission quantum yields of both $\mathrm{H}_{2} \mathrm{~L}^{\mathrm{n}}(\sim 0.01)$ and the corresponding complexes $(\mathbf{1}-\mathbf{6})(\sim 0.02)$ are low, but they are of the same order of magnitude. Thus comparisons of the electronic and emission spectroscopic features of $\mathrm{H}_{2} \mathrm{~L}^{1-3}$ with that of 1-6 indicate that the emission bands displayed by the

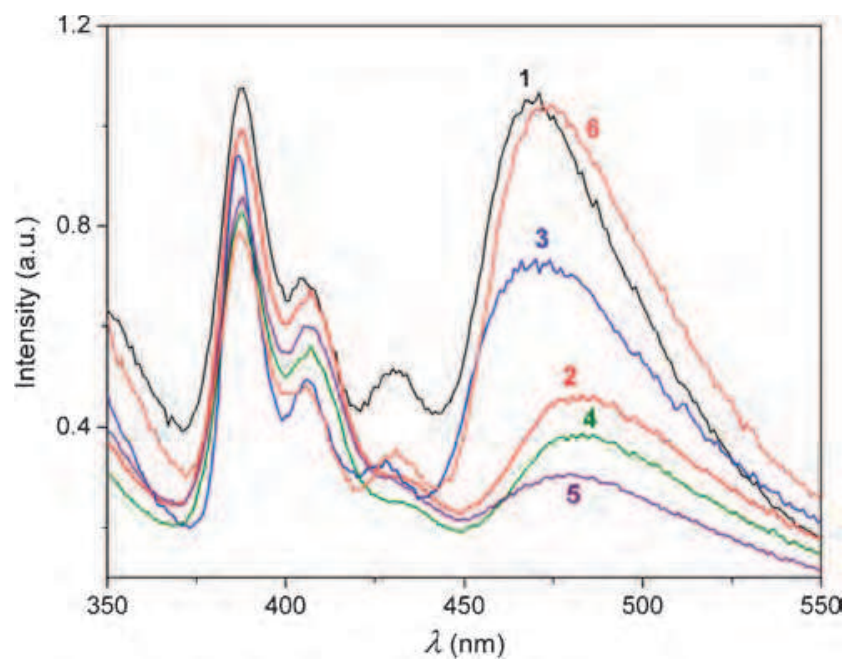

Figure 2. Emission spectra of trans-[Ru( $\left.\left.\mathrm{L}^{\mathrm{n}}\right)(\mathrm{CO})\left(\mathrm{EPh}_{3}\right)_{2}\right]$ $(\mathbf{1}-\mathbf{6})$ in acetonitrile. 
complexes are primarily due to ligand centred emissive states. ${ }^{23,27,52,53}$

\section{$3.3 X$-ray structures of $\mathbf{1}$ and $\mathbf{3}$}

Attempts to grow single crystals of all the complexes (1-6) were made to confirm the coordination modes of the thiosemicarbazonate ligands towards ruthenium(II) and the overall coordination geometry in these complexes by X-ray crystallography. However,

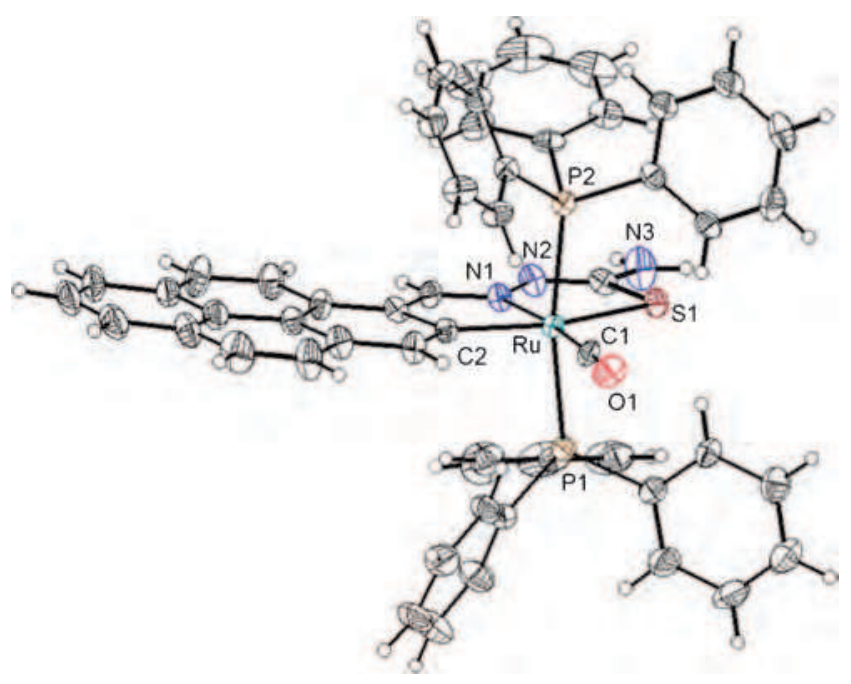

Figure 3. Molecular structure of trans- $\left[\mathrm{Ru}\left(\mathrm{L}^{1}\right)(\mathrm{CO})\left(\mathrm{PPh}_{3}\right)_{2}\right]$ (1). Thermal ellipsoids of all non-hydrogen atoms are at $30 \%$ probability level. For clarity, only the non-carbon and the metal coordinated carbon atoms are labelled.
X-ray quality single crystals of only $\mathbf{1}$ as a solvate $\left(\mathbf{1} \cdot \mathrm{CHCl}_{3} \cdot 0.5 \mathrm{CH}_{3} \mathrm{CN}\right)$ and $\mathbf{3}$ could be obtained. The perspective views of $\mathbf{1}$ and $\mathbf{3}$ are shown in figures 3 and S2 (supplementary information), respectively. The bond parameters involving the metal centres in the two complexes are given in table 2. The gross molecular structures of both the complexes are very similar. In each of $\mathbf{1}$ and $\mathbf{3}$, the meridionally spanning thiosemicarbazonate ligand $\left(\left(\mathrm{L}^{1}\right)^{2-}\right.$ in $\mathbf{1}$ and $\left(\mathrm{L}^{3}\right)^{2-}$ in $\left.\mathbf{3}\right)$ is coordinated to the metal centre through the 1-pyrenyl ortho-C, the azomethine- $\mathrm{N}$ and the thioamidate-S atoms forming 5,5-membered fused chelate rings. Presumably in presence of triethylamine coordination of the monoanionic $\left(\mathrm{HL}^{\mathrm{n}}\right)^{-}$to the metal centre via the azomethine$\mathrm{N}$ and the thioamidate-S atoms brings the 1-pyrenyl ortho- $\mathrm{C}-\mathrm{H}$ in close proximity of the metal centre and hence facilitates its activation and $\mathrm{Ru}-\mathrm{C}$ bond formation. ${ }^{25}$ The carbonyl-C occupies the fourth equatorial coordination site and forms a $\mathrm{C}_{2} \mathrm{NS}$ square plane around the metal centre. As generally expected for hexacoordinated complexes containing $\left\{\mathrm{Ru}\left(\mathrm{PPh}_{3}\right)_{2}\right\}$ unit, the two bulky $\mathrm{PPh}_{3}$ molecules occupy the two axial sites $^{19,20,24,25,28-32,48,51}$ and completes a distorted octahedral $\mathrm{C}_{2} \mathrm{NSP}_{2}$ coordination environment around the ruthenium(II) centre. The $\mathrm{N}(2)-\mathrm{C}(19)$ and $\mathrm{C}(19)-\mathrm{S}(1)$ $(\mathrm{C}(19)$ is the thioamidate-C) bond lengths in $\mathbf{1}(1.300(9)$ and 1.751(8) $\AA$ ) as well as in 3 (1.290(11) and 1.731(11) $\AA$ ) are consistent with the deprotonation of the thioamide functionality in the coordinated thiosemicarbazonate ligands $\left(\mathrm{L}^{1}\right)^{2-}$ and $\left(\mathrm{L}^{3}\right)^{2-}{ }^{28,29,32}$ The bite

Table 2. Selected bond lengths $(\AA)$ and angles $\left(^{\circ}\right)$ for $\mathbf{1}$ and $\mathbf{3}$.

\begin{tabular}{lll}
\hline Complex & 1 & 3 \\
\hline $\mathrm{Ru}-\mathrm{C}(1)$ & $1.817(8)$ & $1.791(10)$ \\
$\mathrm{Ru}-\mathrm{C}(2)$ & $2.065(7)$ & $2.052(8)$ \\
$\mathrm{Ru}-\mathrm{N}(1)$ & $2.103(6)$ & $2.062(7)$ \\
$\mathrm{Ru}-\mathrm{S}(1)$ & $2.4641(19)$ & $2.447(2)$ \\
$\mathrm{Ru}-\mathrm{P}(1)$ & $2.381(2)$ & $2.355(3)$ \\
$\mathrm{Ru}-\mathrm{P}(2)$ & $2.368(2)$ & $2.343(3)$ \\
$\mathrm{C}(1)-\mathrm{Ru}-\mathrm{C}(2)$ & $95.0(3)$ & $95.9(4)$ \\
$\mathrm{C}(1)-\mathrm{Ru}-\mathrm{N}(1)$ & $173.2(3)$ & $174.4(4)$ \\
$\mathrm{C}(1)-\mathrm{Ru}-\mathrm{S}(1)$ & $108.5(2)$ & $106.7(3)$ \\
$\mathrm{C}(1)-\mathrm{Ru}-\mathrm{P}(1)$ & $88.3(2)$ & $90.2(3)$ \\
$\mathrm{C}(1)-\mathrm{Ru}-\mathrm{P}(2)$ & $89.6(2)$ & $89.5(3)$ \\
$\mathrm{C}(2)-\mathrm{Ru}-\mathrm{N}(1)$ & $78.3(3)$ & $78.6(3)$ \\
$\mathrm{C}(2)-\mathrm{Ru}-\mathrm{S}(1)$ & $156.5(2)$ & $157.4(3)$ \\
$\mathrm{C}(2)-\mathrm{Ru}-\mathrm{P}(1)$ & $96.8(2)$ & $92.5(2)$ \\
$\mathrm{C}(2)-\mathrm{Ru}-\mathrm{P}(2)$ & $92.8(2)$ & $91.0(2)$ \\
$\mathrm{N}(1)-\mathrm{Ru}-\mathrm{S}(1)$ & $78.31(16)$ & $78.8(2)$ \\
$\mathrm{N}(1)-\mathrm{Ru}-\mathrm{P}(1)$ & $91.62(18)$ & $89.7(2)$ \\
$\mathrm{N}(1)-\mathrm{Ru}-\mathrm{P}(2)$ & $91.61(18)$ & $90.9(2)$ \\
$\mathrm{S}(1)-\mathrm{Ru}-\mathrm{P}(1)$ & $85.72(7)$ & $87.38(9)$ \\
$\mathrm{S}(1)-\mathrm{Ru}-\mathrm{P}(2)$ & $86.06(7)$ & $89.40(9)$ \\
$\mathrm{P}(1)-\mathrm{Ru}-\mathrm{P}(2)$ & $170.38(7)$ & $176.52(9)$ \\
& &
\end{tabular}


angles $\left(78.3(2)-78.8(2)^{\circ}\right)$ in the 5,5-membered fused chelate rings of both $\mathbf{1}$ and $\mathbf{3}$ are comparable with those reported for other ruthenium(II) complexes containing similar fused chelate rings formed by CNS-donor thosemicarbazonates. ${ }^{28-32}$ The remaining cis bond angles are within the range $85.72(7)-108.5(2)^{\circ}$. In both complexes, the $\mathrm{P}(1)-\mathrm{Ru}-\mathrm{P}(2)$ and $\mathrm{C}(1)-\mathrm{Ru}-\mathrm{N}(1)$ bond angles $\left(170.38(7)-176.52(9)^{\circ}\right)$ formed by the two mutually trans $\mathrm{PPh}_{3}$ ligands and the trans oriented carbonyl-C and the azomethine- $\mathrm{N}$, respectively are somewhat deviated from the ideal value of $180^{\circ}$. As expected, due to steric constraint the trans $\mathrm{C}(2)-\mathrm{Ru}-\mathrm{S}(1)$ bond angle $\left(156.5(2)^{\circ}\right.$ in $\mathbf{1}$ and $157.4(3)^{\circ}$ in 3$)$ formed by the two ends of the CNS-donor $\left(\mathrm{L}^{\mathrm{n}}\right)^{2-}$ is significantly smaller than the above two trans bond angles. On the whole, the $\mathrm{Ru}-\mathrm{C}$ (carbonyl), the $\mathrm{Ru}-\mathrm{C}($ ortho), the $\mathrm{Ru}-\mathrm{N}$ (imine), the $\mathrm{Ru}-\mathrm{S}$ (thioamidate) and the two $\mathrm{Ru}-\mathrm{PPh}_{3}$ bond lengths and the bond angles at the metal centres in both complexes (table 2) are comparable with the corresponding bond lengths and angles reported for similar hexacoordinated bivalent ruthenium complexes. ${ }^{28-32,47,51}$ Considering the similarities in the physical properties of $\mathbf{1 - 6}$, analogous molecular structure is conjectured for each of the six complexes.

\section{Conclusions}

In our attempts to synthesize pincer-type complexes with potentially CNS-donor 1-pyrenaldehyde 4- $R$-3thiosemicarbazones $\left(\mathrm{H}_{2} \mathrm{~L}^{\mathrm{n}}\right)$, a new series of regioselectively cyclometallated ruthenium(II) carbonyl complexes has been isolated via a convenient synthetic method. The general molecular formula of these diamagnetic complexes has been established as trans$\left[\mathrm{Ru}\left(\mathrm{L}^{\mathrm{n}}\right)(\mathrm{CO})\left(\mathrm{EPh}_{3}\right)_{2}\right]$ (where $\mathrm{E}=\mathrm{P}$ or As) by microanalytical and various spectroscopic measurements. All the complexes display ligand-centred absorption and emission maxima. Single crystal X-ray diffraction studies with representative complexes revealed the meridionally spanning CNS coordination mode of the thiosemicarbazonate ligand $\left(\left(\mathrm{L}^{\mathrm{n}}\right)^{2-}\right)$ through its 1-pyrenyl ortho- $\mathrm{C}$, the azomethine- $\mathrm{N}$ and the thioamidate-S atoms and formation of 5,5-membered fused chelate rings. Thus as observed earlier for the trivalent ruthenium complexes with $\mathrm{CNO}$-donor aroylhydrazones of polycyclic aromatic aldehydes, ${ }^{25,26}$ the 1-pyrenyl group in the present series of divalent ruthenium complexes also undergoes regioselective ortho-metallation. We are currently trying to isolate previously elusive ${ }^{28}$ pincer-type cyclometallated complexes with thiobenzhydrazones of polycyclic aromatic aldehydes using synthetic methods analogous to that reported here.

\section{Supplementary Information}

CCDC 1016390 and 1016391 contain the supplementary crystallographic data for $1 \cdot \mathrm{CHCl}_{3} \cdot 0.5 \mathrm{CH}_{3} \mathrm{CN}$ and $\mathbf{3}$, respectively. These data can be obtained free of charge via www.ccdc.cam.ac.uk/data_request/cif. Figures $\mathrm{S} 1$ and $\mathrm{S} 2$ can be seen at www.ias.ac.in/ chemsci.

\section{Acknowledgements}

Dr. R. N. Prabhu is grateful to the University Grants Commission (UGC), New Delhi for the financial support under the Dr. D. S. Kothari Postdoctoral Fellowship Scheme (No. F. 13-897/2013(BSR)). We thank the Department of Science and Technology (DST), New Delhi and the UGC for the facilities provided under the FIST and the CAS programmes, respectively.

\section{References}

1. Ackermann L 2014 Acc. Chem. Res. 47281

2. Lau C P, Ng S M, Jia G and Lin Z 2007 Coord. Chem. Rev. 2512223

3. Wenger O S 2009 Coord. Chem. Rev. 2531439

4. Hammarström L and Johansson O 2010 Coord. Chem. Rev. 2542546

5. Mercs L and Albrecht M 2010 Chem. Soc. Rev. 391903

6. Dragonetti C, Valore A, Colombo A, Robertoa D, Trifiletti V, Manfredi N, Salamone M M, Ruffo R and Abbotto A 2010 J. Organomet. Chem. $\mathbf{7 1 4} 88$

7. Singh A K, Shankar D, Xua Q and Braunstein P 2014 Coord. Chem. Rev. 270-271 31

8. Cutillas N, Yellol G S, de Haro C, Vicente C, Rodríguez V and Ruiz J 2013 Coord. Chem. Rev. 2572784

9. van der Boom M E and Milstein D 2003 Chem. Rev. 103 1759

10. Prabhu R N and Ramesh R 2012 J. Organomet. Chem. 71843

11. Poyatos M, Mata J A, Falomir E, Crabtree R H and Peri E 2003 Organometallics 221110

12. Lee C-S, Zhuang R R, Wang J-C, Hwang W-S and Lin I J B 2012 Organometallics 314980

13. Wang C-H, Ma N-N, Sun X-X, Sun S-L, Qiu Y-Q and Liu P.-J 2012 J. Phys. Chem. A 11610496

14. Haga M-a, Takasugi T, Tomie A, Ishizuya M, Yamada T, Hossain M D and Inoue M 2003 Dalton Trans. 2069

15. Gagliardo M, Chase P A, Lutz M, Spek A L, Hartl F, Havenith R W A, van Klink G P M and van Koten G 2005 Organometallics 244553

16. Gunanathan C and Milstein D 2008 Angew. Chem. Int. Ed. 478661

17. Das S and Pal S 2004 J. Organomet. Chem. 689352

18. Das S and Pal S 2006 J. Organomet. Chem. 6912575

19. Raveendran R and Pal S 2007 J. Organomet. Chem. 692 824 
20. Raveendran R and Pal S 2009 J. Organomet. Chem. 694 1482

21. Rao A R B and Pal S 2011 J. Organomet. Chem. 696 2660

22. Rao A R B and Pal S 2012 J. Organomet. Chem. 70162

23. Rao A R B and Pal S 2013 J. Organomet. Chem. 73167

24. Nagaraju K and Pal S 2013 J. Organomet. Chem. 7377

25. Nagaraju K and Pal S 2013 J. Organomet. Chem. 745746404

26. Rao A R B and Pal S 2014 J. Organomet. Chem. 76258

27. Nagaraju K and Pal S 2014 Inorg. Chim. Acta 413102

28. Prabhu R N, Pandiarajan D and Ramesh R 2009 J. Organomet. Chem. 6944170

29. Chowdhury N S, Seth D K, Drew M G B and Bhattacharya S 2011 Inorg. Chim. Acta 372183

30. Lobana T S, Bawa G, Castineiras A, Butcher R J and Zeller M 2008 Organometallics 27175

31. Mandal S, Seth D K and Gupta P 2013 Inorg. Chim. Acta 39710

32. Dutta S, Basuli F, Castineiras A, Peng S-M, Lee G-H and Bhattacharya S 2008 Eur. J. Inorg. Chem. 4538

33. Lobana T S, Sharma R, Bawa G and Khanna S 2009 Coord. Chem. Rev. 253977

34. Ahmed N, Levison S J, Robinson S D and Uttley M F 1974 Inorg. Synth. 1548

35. Sanchez-Delgado R A, Lee W Y, Choi S R, Cho Y and Jun M J 1991 Transition Met. Chem. 16241

36. Armarego W L F and Chai C L L 2009 In Purification of Laboratory Chemicals (6th Ed.) (Oxford: ButterworthHeinemann) p. 69

37. Demeter A 2014 J. Phys. Chem. A 1189985

38. SMART Version 5.630 and SAINT-plus Version 6.45 2003 Bruker-Nonius Analytical X-ray Systems Inc., Madison, Wisconsin, USA
39. Sheldrick G M 1997 SADABS, Program for Area Detector Absorption Correction, University of Göttingen, Göttingen, Germany

40. CrysAlisPro 2013 Version 1.171.36.28, Agilent Technologies, Yarnton, Oxfordshire, UK

41. Altomare A, Cascarano G, Giacovazzo C, Guagliardi A, Burla M C, Polidori G and Camalli M 1994 J. Appl. Crystallogr. 27435

42. Sheldrick G M 2008 Acta Crystallogr., Sect. A 64112

43. Farrugia L J, 1999 J. Appl. Crystallogr. 32837

44. Spek A L 2002 Platon, A Multipurpose Crystallographic Tool, Utrecht University, Utrecht, The Netherlands

45. Macrae C F, Bruno I J, Chisholm J A, Edgington P R, McCabe P, Pidcock E, Rodriguez-Monge L, Taylor R, van de Streek J and Wood P A 2008 J. Appl. Crystallogr. 41466

46. Wang X M, Yan H, Feng X L and Chen Y 2010 Chin. Chem. Lett. 211124

47. Lobana T S, Bawa G, Butcher R J, Liaw B-J and Liu C W 2006 Polyhedron 252897

48. Kannan S, Sivagamasundari M, Ramesh R and Liu Y 2008 J. Organomet. Chem. 6932251

49. Beckford F A, Shaloski M Jr, Leblanc G, Thessing J, Lewis-Alleyne L C, Holder A A, Li L and Seeram N P 2009 Dalton Trans. 10757

50. Vijayan P, Viswanathamurthi P, Silambarasan V, Velmurugan D, Velmurugan K, Nandhakumar R, Butcher R J, Silambarasan T and Dhandapani R 2014 J. Organomet. Chem. 768163

51. Prabhu R N and Ramesh R 2012 RSC Adv. 24515

52. Lentijo S, Miguel J A and Espinet P 2011 Organometallics $\mathbf{3 0} 1059$

53. Wheatley A D and Sadhra S 1998 J. Liq. Chrom. Rel. Technol. 212509 